\title{
URGENSI RETORIKA DALAM AKTIVITAS DAKWAH
}

\author{
Mohd. Rafiq \\ Lecturer of Da'wah and Communication Sciences Faculty at IAIN Padangsidimpuan \\ Jl. T. Rijal Nurdin Km.4,5 Sihitang Padangsidimpuan 22733 \\ Email: mohd.rafiqs.ma@gmail.com
}

\begin{abstract}
Art and the ability to speak (rhetoric) in front of audiences is needed in various dimensions of life, especially regarding the profession as a da'i. For a preacher (da'i), rhetoric is very vital and urgent to be mastered, because its significance to the way of dakwah islamiyah. Rhetoric intended to convey the truth of the Quran and Hadith, to change the audience to run a of the commanding of Allah to the amar ma'ruf nahi munkar. Practically, rhetoric becomes a necessity for the preacher to be able to carry out the mission of preaching in an orderly, well-planned, structured, conceptualized, and systematic.Many verses of the Qur'an lead preachers to use good rhetoric (fannul khitabah) for doing the activity of dakwah. In surah An-Nahl verse 125, Allah explains that, dakwah activity must be done with hikmah, mau'izhah and Mujadalah. Mujadalah (dialogue in a good way) in this case is understood as a form of rhetoric. Furthermore, the surah Fushilat verse 33 Allah states that the best word (rhetoric) is to call people when carried into the path of Allah (da'wah). It means that calls to the path of Allah is an activity that is best therefore these efforts should also be done in the best way anyway, having 'stance, continuous and without knowing despair coupled with the nature of genuine (sincere) solely because of God
\end{abstract}

Keyword: Urgency, Rhetoric, Activity, Da'wah

\begin{abstract}
Abstrak
Seni dan kemampuan berbicara (retorika) di depan khalayak yang dibutuhkan dalam berbagai dimensi kehidupan, terutama mengenai profesi sebagai da'i a. Untuk seorang pengkhotbah (da'i), retorika sangat penting dan segera untuk dikuasai, karena maknanya dengan cara dakwah islamiyah. Retorika dimaksudkan untuk menyampaikan kebenaran Al-Quran dan Hadis, untuk mengubah penonton untuk menjalankan dari perintah Allah dengan amar ma'ruf nahi munkar. Bisa dibilang, retorika menjadi suatu keharusan bagi pendeta untuk dapat melaksanakan misi dakwah secara tertib, terencana, terstruktur, dikonsep, dan systematic.Many ayatayat Al-Qur'an menyebabkan pengkhotbah untuk menggunakan retorika yang baik (khitbah fannul ) untuk melakukan aktivitas dakwah. Dalam surah An-Nahl ayat 125, Allah menjelaskan bahwa, kegiatan dakwah harus dilakukan dengan hikmah, mauizah dan Mujadilah. Mujadilah (dialog dalam cara yang baik) dalam hal ini dipahami sebagai bentuk retorika. Selain itu, surah Fussilat ayat 33 Allah menyatakan bahwa yang terbaik kata (retorika) adalah untuk memanggil orang-orang ketika dibawa ke jalan Allah (dakwah). Ini berarti bahwa panggilan ke jalan Allah adalah kegiatan yang terbaik karena itu upaya ini juga harus dilakukan dengan cara yang terbaik pula, memiliki 'sikap, terus menerus dan tanpa mengetahui putus asa ditambah dengan sifat asli (tulus) semata-mata karena Allah.
\end{abstract}

Kata Kunci: Urgensi, Rhetorika, Kegiatan, Dakwah 
FITRAH Vol.01 No. 1 Januari-Juni 2015

\section{PENDAHULUAN}

Pada umumnya persepsi masyarakat tentang kemajuan yang diperolrh Barat saat ini hanya bertumpu pada sains, teknologi, matematika, kimia atau ilmu eksak lainnya. Padahal sebelum kemajuan sains dan teknologi itu diperoleh, ternyata dunia Barat sejak berabad-abad lamanya telah berpijak pada kultur pendidikan bahasa yang berakar pada filsafat Yunani dan bertumpu pada retorika. Pada sisi lain persepsi masyarakat mengenai retorika cenderung subordinat, seolah-olah retorika hanyalah dimaksudkan sebagai propaganda belaka, dengan kata -kata yang bagus kedengarannya tetapi kualitas isinya disangsikan.

Mangunwijaya, ${ }^{1}$ mengatakan bahwa makna mendalam dari retorika itu adalah pemekaran bakat-bakat tertinggi manusia, yakni rasio dan cita rasa lewat bahasa selaku kemampuan untuk berko-munikasi dalam medan pikiran. Retorika dalam perkembangan berikutnya menjadi mata ajar yang sangat sentral menuju emansipasi manusia untuk menjadi dirinya sendiri. Di Amerika Serikat retorika begitu sentral posisinya, sehingga dalam semua jurusan pendidikan tinggi retorika menjadi mata kuliah wajib.

\section{PENGERTIAN RETORIKA}

Retorika dalam bahasa Inggeris rhetoric, dan dalam bahaqsa latin disebut rhetorica yang berarti "ilmu bahasa". Cleanth Brooks dan Robert Peen (dalam Effendy), mendefinisikan retorika sebagai seni menggunakan bahasa secara efektif. Dalam pengertian sempit, diartikan sebagai ilmu bicara, edangkan secara luas pengertian retorika kemudian dimaksudkan sebagai kemampuan bahasa (lisan maupun tulisan). ${ }^{2}$

Retorika dalam perkembangselanjutnya sering diidentikkan dengan public speaking (kemampuan berbicara didepan umum) . banyak juga yang berpendapat bahwa retorika tidak hanya kemampuan berbicara di depan umum, tetapi juga termasuk seni menulis. itulah sebabnya para ahli komunikasi lebih cenderung menempatkan retorika sebagai gabungan seni berbicara di hadapan orang banyak dan pengetahuan untuk meyakinkan orang lain terhadap suatu masalah melalui pendekatan persuasi ${ }^{3}$.

Retorika dikatakan sebagai seni karena menuntut keahlian dan keterampilan (skill) dalam penguasaan bahasa. Dikatakan sebagai pengetahuan karena retorika memiliki sekumpulan materi atau masalah yang harus disampaikan kepada pihak lain. Selain itu dalam retorika, kemampuan berlogika sangat menjadi pertimbangan, karena untuk menyampaikan sebuah gagasan atau ide kepada orang lain tidak hanya sekedar berbicara tetapi menyampaikan dengan penuh penjelasan, misalnya mengikutsertakan contoh, anekdot, lambing-lambang dan sebagainya secara logis agar mudah difahami, dimengerti dan ditindaklanjuti lawan bicara.

${ }^{1}$ Mangunwijaya, Y.B. Pendidikan Manusia Merdeka. Kompas 11 Agustus 1992

2Onong Uchjana Effendi.Ilmu Komunikasi Teori dan Praktek.(Bandung: PT. Remaja Rosdakarya, 1999$)$, hlm. 53.

${ }^{3}$ Toto Tasmara, Komunikasi Dakwah. (Jakarta: CV. Gaya Media Pratama, 1987), hlm. 136 
Oleh karena itu paling tidak menurut Toto Tasmara;beberapa hal yang paling dominan dalam retorika adalah hal-hal yang menyangkut kemampuan berbahasa, pengetahuan atas bahasa (massege, kelincahan berlogika, penguasaan psikologi massa dan pengetahuan atas system sosial budaya masyarakat yang dihadapi. ${ }^{4}$

\section{JENIS-JENIS RETORIKA (PIDATO)}

Ernest G Bormann dan Nancy C Bormann ${ }^{5}$, membagi jenis pidato kepada tiga jenis, yakni pidato informatif, pidato argumentatif, pidato persuasif. Menurut Rakhmat, jenis pidato terdiri dari; pidato informatif, pidato persuasif, dan pidato rekreatif. Pidato informative bertujuan untuk menjelasakan masalah atau persoalan tertentu kepada audiens.Sedangkan Ehninger, Monroe, dan Gronbeck ${ }^{6}$ ( dalam Rakhmat), tiga macam pidato informasi: pertama, oral reports (laporan lisan), laporan ilmiah, laporan panitia, laporan tahunan, laporan proyek dan sebagainya. Kedua, oralinstruction (pengajaran); guru menjelaskan pengajaran, atasan menerangkan pekerjaan, pimpinan membagi tugas kepada bawahan dan sebagainya. Ketiga, informative lectures (kuliah) ; ceramah umum, presentasi di depan peserta konferensi, penyajian makalah, pengajian dan sebagainya.

Pidato informatif dilakukan dalam upaya untuk menanamkan pengertian kepada audiens. Oleh karena itu, pidato informative disampaikan secara jelas, logis dan sistematis. Audiens akan sulit memahami pesan yang abstrak, zig-zag atau kacau. Pidato argumentatif biasanya dilakukan orator untuk memberikan argumentasi kepada audiens sebagai pendukung pendapa dan mengambil masalah kontrovessial untuk kemudian dianalisis dengan cara yang koheren dan berdasarkan logika. Dalam argumentasi, ada hal-hal yang disetujui dan tidak disetujui. Tentu saja dalam hal ini seseorang harus menjelaskan dengan baik mengapa ia setuju dan mengapa pula ia tidak setuju, kemudian memfokuskan perbedaan dengan pendapat orang lain dengan jelas. Untuk tujuan ini dibutuhkan kemampuan berlogika sebagai proses konklusi dari satu pokok masalah atau lebih yang dipakai sebagai asumsi atau dasar pikiran atau hal-hal yang perlu dibuktikan dengan fakta.

Jika ingin mencek logika, camkanlah bahwa fakta harus berhubungan dengan pokok masalah yang ingin dibuktikan dan alas an yang diberikan harus mendukung konklusi. Bormann dan Bormann, mengatakan bahwa fakta adalah bahan yang dipakai untuk membuat percaya atau meyakinkan kebenaran atau kepalsuan, ketepatan atau kekeliruan, kebijakan atau ketololansebuah dalil. ${ }^{7}$ Fakta yang sah mungkin dapat merupakan pengakuan saksi mata, dokumen tertulis, atau barang bukti lainnya. Sedangkan

${ }^{4}$ Ibid. hlm. 137

${ }^{5}$ Ernest G. Bormann dan Nancy C Bormann, Speech Communication A Basic Approach. Terj. Paulus Sulasdi. Retorika Suatu Pendekatan Terpadu.(Jakarta: Erlangga, 1991), hlm. 181.

6 Jalaluddin Rahmad, Rhetorika Modern, Pendekatan Praktis. (Bandung: PT. Remaja Rosdakarya, 2000), hlm. 89.

7Bormann dan Bormann, Speech Communication....1991, hlm. 196 
FITRAH Vol.01 No. 1 Januari-Juni 2015

pembuktian adalah proses dari pengumpulan, penyusunan, dan pemberian fakta yang memada'i untuk meyakinkan audiens untuk menerima suatu pemikiran. Statistic dan kesaksian merupakan bahan yang dapat dipergunakan untuk mendukung langkah argumentative ini,

Retorika sering diiden-tikkan dengan teknit persuasi.Pidato persuasif dimaksudkan sebagai upaya untuk mengubah perilaku audiens, mengubah sikap atau keyakinan, mempengaruhi orang lain, menggalang persatuan maupun menjual produk atau ide ${ }^{8}$. Sedangkan Rakhmat (2000;102), mengatakan proses mempengaruhi tersebut dengan menggunakan manipulasi psikologis sehingga audiens bertindak seperti atas kehendak orator. Pendapat, sikap dan tindakan adalah fenomena kepribadian, karena itu seorang orator perlu mengetahui faktor-faktor yang menemukan kepribadian manusia9 .

Dalam pidato rekreatif (menghibur) sebenarnya dimak-sudkan isi pidato seluruhnya tidak harus selalu melucu (lelucon). Tujuannya adalah untuk menggembirakan, mele-paskan ketegangan, menggai-rahkan suasana atau sekedar memberikan selingan yang enak setelah rangkaian acara yang melelahkan.Pidato rekreatif disampaikan dalam beberapa situasi, misalnya perhelatan atau pesta. Pertemuan kelompok (keluarga, organisasi social, klub dan sebagainya), atau pada jamuan makan malam. Pidato rekreatif ini disampaikan oleh orang yang berwajah ceria, riang, gembira, santai, "easy going". Dalam pidato ini orator ingin menyenangkan hati audiens yang tersimbol melalui tertawa, oleh karenanya perlu dipelajari beberapa teori humor.

Selanjutnya Ya'qub ${ }^{10}$, membagi jenis pidato yang disebutnya dengan langgam pidato sebagai berikut; pertama, langgam khutbah, suara tidak tetap dalam suatu status melainkan mempunyai gaya tempo naik dan turun, diucapkan lambat tetapi jelas. Langgam ini dipergunakan untuk khutbah-khutbah. Kedua, langgam sentimentil; langgam ini dipergunakan untuk membangkitkan emosi audiens dengan cara menyampaikan pidato dengan penuh perasaan, kata-kata singkat dan padat, misalnya panggilan untuk melaksanakan jihad. Ketiga, langgam agitator dipergunakan secara ekspilosif atau agresif untuk menyerang lawan dengan argument yang mantap. Biasanya langgam ini dipergunakan dalam rapat-rapat yang bersifat politik. Keempat, langgam theatraal; yang lebih mempergunakan action, merupakan orang yang sedang bermqain sandiwara. Kelima, langgam conversative; dalam lingkungan yang terbatas,berbicara dengan tenang dan bebas, seperti pada saat orang sedang melakukan silaturrahmi biasa. Keenam,langgam didaktik; dipergunakan dalam kuliahdan memberikan pelajaran. 


\section{TEKNIK PRAKTIS TAHAPAN PIDATO}

Sebelum da'i menjalankan aktivitas dakwahnya, terlebih dahulu dipersiapkan beberapa langkah (tahapan ) sehingga autput dakwah yang dilakukan membernilai yang berarti. Paling tidak ada tiga tahapan yang harus dipersiapkan seorangda'i dalam menjalankan pidato di tahapan Khalayak, yakni; pertama, tahapan persiapan (misalnya; menetukan jenis pidato, memilih topik dan tujuan serta mengembangkan bahasan). Kedua, tahap penyusunan pidato. Pada tahap ini da'i harus menetukan prinsip-prinsip komunikasi pidato, menyusun pesan pidato, membuat garis-garis besar pidato, memilih kata-kata, membuat bagan sebuah pidato (cara membuka dan menutup pidato). Ketiga, tahap penyampaian pidato. Pada tahap ini yang perlu diperhatikan adalah membangun kepercayaan diri dan krebilitas da;i serta prinsip-prinsip penyampaian pidato harus dikuasai. Pada tahap persiapan pidato, biasanya sangat dibantu oleh kebiasaan yang ada di tempat da'i melakukan aktivitas pidatonya. Misalnya kapan audiens berkumpul, kapan pidato harus dimulai, berapa lama waktu yang disediakan kepada da'i,apakah pidato berlangsung diudalam ruangan atau di lapangan, berdiri atau duduk, menggunakan mimbar (podium) atau tidak, bagaimana kuantitas dan kualitas audiens (anak-anak, remaja, orang tua, ibu-ibu perwiritan, STM bapak-bapak, dan sebagainya).

Oleh karena itu da'i harus terlebih dahulu mencari tahu apa yang menjadi kebutuhan dan keinginan audiens (need and interest audiens). Pada umumnya khalayak sangat mengharap bahwa seorang orator (da'i) akan memberikan pesan yang luas, yang dapat memberikan nilai tambah bagi mereka setelah mendengar pidato tersebut. Itulah sebabnya mengapa da'i perlu mempersiapkan kualitas materi (substansi) ceramah atau pidatonya.

Teknik penyajian yang biasanya sering dilakukan dalam retorika, menurut Tasmara ${ }^{11}$ adalah sebagai berikut: pertama, membuat suatu pendahuluan sebagai introduksi. Kedua. Mengemukakan suatu masalah dan membahsnya sejelas mungkin (narratio atau pemaparan). Ketiga, melakukan pembuktian-pembuktian (comfirmation) dari masalah yang dipaparkan, sehingga khalayak merasakan kebenaran atau manfaat dari topik yang sedang dibicarakan. Keempat, mencari fakta atau dukungan sebagai tambahan, misalnya dari pendapat tokoh \para pakar bidang tertentu untuk menanamkan sugesti dan sebagainya referensi pembicaraan sehingga memiliki nilai reputasi atas bobot pembicaraan (reputation). Kelima, menyimpulkan hasil pembuktian dari pembicaraan sebagai bagian penutup (peroratio).

Dalam dunia retorika, para ahli pidato (orator) mempunyai pegangan yang selalu dipedomani "Qui ascendit sine labore, descendit sine honore" (naik tanpa persiapan, turuntanpa penghormatan). Pedoman ini harus selalu dikumandangkan dalam diri da'i sehingga diperlukan beberapa persiapanpidato secara teliti dan seksama.

11Toto Tasmara, Komunikasi..... hlm. 140-141 
FITRAH Vol.01 No. 1 Januari-Juni 2015

Ada dua cara yang ditempuh dalam melaksanakan proses pidato, yakni dengan menggunakan naskah dan tanpa menggunakan naskah. Ini tentu saja tergantung pada situasi, sifat pelaksanaan, pesan yang akan disampaikan, secara audiens yang dihadapi. Pada pidato tanpa naskah dapat membangun hubungan atau kontak pribadi (personal contract) antara da'i dengan audiensnya. Pidato dalam konteks ini menyebabkan audiensnya. Menaruh kepercayaan penuh kepada da'i, karena apa yang disampaikan da'i biasanya merupakan hasil pencetusan idea tau pemikirannya sendiri. Tentu saja model pidato ini dilakukan dalam suatu pertemuan yang analisa resikonya minimal.

Untuk pemula, bila menggunakan pidato model ini biasanya menuliskan dalam kertas kecil term of reference atau pokok-pokok bahasan pidato secara garis besar. Pengembangannya kemudian dilakukan diatas mimbar (pada saat pidato dilangsungkan). Tetapi ada juga yang terlebih dahulumenuliskan naskah pidatonya; kemudian dihafal sehingga tidak terjadi pengembangan pembicaraan di atas mimbar, yang terjadi adalah menyampaikan seluruh isi pidato sesuai dengan hafalan naskah sebelumnya.

Para orator yang sudah terbiasa (mahir) kadang kala tanpa konsep, tanpa hafalan, tanpa term of reference, ia bisa mengembangkan materi pidatonya di atas mimbar, melebar kesana kemari, kemudian sampai pada titik tujuannya isi pidato sesuai denganfeet back yang diberikan audiens. Dengan kemampuan yang dimiliki da'i seperti yang disebutkan terakhir sangat membantu membuat suasana familiar antara da'i dengan audiens, bahkan kadangkala sanggup mempesona hadirin (pendengar).

Sedangkan pada pidato dengan cara menggunakan naskah, dilakukan pada acara resmi (formal), acara kenegaraan dan sebagainya. Pada model ini, bahasa yang disampaikan telah tersusun dengan baik dan benar susunan kalimatnyajuga teratur, kata-katanya tepat kontinuitasnya terjamin. Kelemahannya tentu saja hubungan akrab antara da'i dengan audiens kurang terjalin, sehingga meyebabkan feed back yang diberikan audiens kurang menguntungkan da'i .

Dalam melakukan pengembangan topik bahasan dalam sebuah pidato, perlu diperhatikan keterangan penunjang (supporting points) yang digunakan untuk memperjelas uraian, memperkuat kesan menambah daya tarik dan mempermudah pengertian. ${ }^{12}$ Teknik mengembangkan bahasan dikelompokkan kepada enam macam; penjelasan, contoh, analogi, testimoni, statistic, dan perulangan.

Penjelasan dimaksudkan memberikan pendengar keterangan yang sederhana dan tidak terinci. Biasanya dilakukan dengan defenisi atau alat-alat visual. Defenisi adalah keteranga tentang suatu kata atau istilah. Sedangkan contoh diberikan dalam rangka mengkongriktkan gagasan, ide da'i sehingga mudah difahami audiens. Cerita yang sebenarnya terjadi dalam khazanah kehidupan, kisah orang-orang besar atau peristiwa

12 Jalaluddin Rahmad Rhetorika Modern....2002, hlm. 25 
actual dapat dipakai untuk mempermudah audiens meahami isi pidato. Analogi merupakan perbandingan dua hal atau lebih untuk menunjukkan persamaan maupun perbedaannya.

Membandingkan antara manusia dengan monyet secara biologi salah satu bentuk analogi. Da'i seringkali menggunakan analogi kiasan, objek-objek yang diperbandingkan tidak termasuk kelompok yang sama. Testimoni adalah pernyataan ahli yang dikutip untuk menunjang kualitas pembicaraan, misalnya kutipan dari Al-Quran dan Hadis, UndangUndang, pendapat para pakar dalam bidang keahliannya dan sebagainya. Statistik adalah angka-angka yang dapat dipergunakan untuk menunjukkan perbandingan kasus dalam jenis tertentu.

Dalam hal ini manfaat statistik dipergunakan da'i untuk menimbulkan kesan yang kuat, memperjelas dan meyakinkan audiens terhadap data maupun fakta yang disajikan. Sedangkan perulangan dimaksudkan untuk lebih dapat menimbulkan kesan yang kuat. Perulangan dalam hal ini bukan saja mengulangi kata-kata yang diucapkan sebelumnya, mengucapkan gagasan yang sama dengan menggunakan kata-kata atau istilah yang berbeda, tetapi maknanya sama. Keenam cara di atas digunakan secara berganti-ganti dalam proses pidato untuk menyampaikan pesan kepada audiens dengan memiliki nilai komunikasi yang efektif.

Untuk memulai menyusun sebuah pidato, ada ungkapan yang perlu direnungkan, "bila tentara bermain-main dengan peluru, maka orator berkecimpung dengan kata-kata". Penggunaan bahasa, pemilihan kata-kata akan memungkinkan da'i untuk memperoleh kefasihan yang memukau. Untuk menyuusun sebuah sistematika pidato yang baik Cicero (106 -43 SM) dalam bukunya De Oratore yang terdiri dari 7 jilid, yang belakang ini dikenal dengan teori kuda, yaitu terdiri dari; kepala (exordium), punggung (protesis), perut (argument), dan ekor (conclusion).13

Kerangka suatu pidato dimulai dari pendahuluan, fungsinya untuk mengantar kearah pokok persoalan yang akan dibahas dansebagai upaya menyiapkan mental para audiens (mental Preparetion). Dalam hal ini da'i perlu membangkitkan perhatian (attention arousing). Timbulkan kesan memikat, ingat petuah sebuah iklan "kesan pertama begitu menggoda, selanjutnya terserah anda". Cara-cara menarik yang perlu ditampilkan para da'i untuk menarik simpati audiens, misalnya dengan mengemukakan kutipan ayat atau hadis, mengajukan pertanyaan, memberikan illustrasi yang spesifik, menyampaikan sebuah fakta yang mengejutkan, menceritakan pengalaman ganjil dan sebagainya.

Tetapi yang perlu diingat jangan sekali-kali memulali pidato dengan permintaan maaf karena khwatir si da'i tidak mampu, tidak memiliki persiapan yang cukup, isi yang tidak sesuai dengan keinginan audiens. Segala bentuk kesan khawatir seperti itu dapat mengurangi dan meruntuhkan kepercayaan dan minat audiens terhadap kualitas da'i. Kalau

${ }^{13}$ T.A. Lathief Rousydiy, Dasar dasar Rhetorica Komunikasi dan Informasi, (Medan: Firma Rimbow, 1989), hlm. 253-256 
itu perlu dilakukan maka, letakkan diakhir pidato bukan dikalimat pembuka pidato (pemdahuluan).

Bormann dan Bormann mengingatkan para pembicara yang kadang-kadang sering melalikan kebiasaan yang berlaku di tengah masyarakat yang dihadapi, misalnya dengan memasukkan unsur-unsur baru dalam memulai pidato. ${ }^{14}$ Memang itu perlu, tetapi melanggar sejumlah adat dan kebiasaan setempat, menyebabkan audiens akan bingung, bosan bahkan marah. Misalkan saja seorang da'i memulai sebuah materi pidato yang sangat seriuas dengan humor, atau da'i tampil dengan pakaian yang tidak biasa di mata audiens, gaya berbicara, dialek, dengan mengeluarkan kata-kata atau humor yang tidak pantas, atau tampil dalam keadaan mabuk, jelas hal ini akan mengganggu suasana audiens.

Pada tahap protesis (isi) atau diibaratkan sebagai punggung kuda, pokok bahasan dengan ditampilkan terlebih dahulu mengemukakan latar belakang permasalahan yang akan dibahas. Ini penting disampaikan untuk menarik garis lurus dengan kepentingan para audiens tentang maeri pidato yang akan disampaikan da'i. materi akan lebih komunikatif bila da'i mengemukakan bahasa yang mudah dipahami dan dicerna oleh para audiens. Jangan sempat istilah yang disampaikan menjadi PR baru bagi audiens, sehingga materi (pesan) pidato tidak sempat ditanggap audiens. Kalau ada istilah penting yang tidak bisa dihindari dari kata-kata yang sulit, da'i perlu menjelaskan dengan menggunakan makna konotatif dari istilah yang dimaksud.

Pada setiap argumenta merupakan bagian perut dari teori kuda, dimaksud sebagai tubuh dari naskah pidato. Argumenta adalah alas an yangmendukung hal-hal yang dikemukakan pada bagian protesis. Jadi ada pendapapendapat para ahli yang tidak sesuai atau bertentangan dengan pendirian da'i, maka pada bagian inilah dilakukan klarifikasi pendapat.

Tahap conclucio merupakan kesimpulan isi pidato. Kesimpulan bukan dimaksudkan sebagai rangkuman penjelasan sebelumnya, tetapi merupakan penegasan, hasil pertimbangan yang mendukung justifikasi atau pembenaran menurut kemampuan penalaaran da'i. Penyampaiannya harus singkat, padat dan sederhana, disusun sedemikian rupa sehingga menjadi kesan yang mengesankan bagi audiens. Pada bagian ini harus diperhatikan; jangan mengemukakan fakta baru, jangan menggunakan kata-kata mubadzir yang tidak fungsional sehingga dapat mengganggu uraian sebelumnya, jangan menampilkan hal-hal yang menimbulkan antiklimaks.

Perlu dicatat dalam mengakhiri sebuah pidato berhentilah pada saat audiens sedang dalam kondisi puncak, audiens sedang merasa serius betul mendengarkan materi ceramah da'i. Hal ini bertujuan membuat audiens penasaran, sehingga audiens tidak puas terhadap materi ceramah da'i (makalah ini terjadi, audiens terus mencari dan mengikuti dakwah yang 
dilakukan sang da'i). Dengan catatan bahwa materi yag disajikan telah sampai kepada substansi pembahasan, bukan dimaksudkan untuk meninggalkan materi ceramah di tengah jalan.

Dalam melakukan sebuah pidato, seringkali da'i pemula maupun yang sudah profisional mengalami gejala demam panggung (stage fright), kecemasan bicara (speech anxiety) atau lebih umum dikenal stress kerja (performance stress). Biasanya orang yang berbicara di bawah tekanan, di bawah pengawasan orang lain akan mengalami gejala reaksi alamiah psikologis. Hal ini adalah wajar, karena sertiap makhluk yang mengalami ancaman maupun tekananalan melawan (fight) atau melarikan diri (flight).

Secara alamiah kondisi di atas dafat dijelaskan, karena sistem saraf simpatetisnya berguncang, adrenalin dan kadar gula dalam pembuluh darah meningkat, tiba tiba dalam tubuh ada tumpukan energi. Semuanya adalah upaya tubuh untuk menyesuaikan diri dengan tekanan dan ancaman tadi. Perilaku di atas disebut sebagai Sindrom Mekanisme Penyesuaian (General Adaption Syndromes) disingkat GAS. GAS tidak perlu dihilangkan, tetapi perlu dijinakkan, oleh karenanya untuk meminimalisirnya perlu diketahui beberapa penyebab timbulnya kecemasan dalam komunikasi, yakni:

Pertama, faktor tidak tahu apa yang harus dilakukan. Untuk mengantisipasinya perlu latihan dan pengalaman. Pengetahuan tentang retorika memudahkanda'i untuk memulai, melanjutkan, mengakhiri pembicaran. Latikan akan memberikan pengalaman. Dale Carnegie memberikan nasehat, "lakukan apa yang anda takut melakukannya". Dengan latihan dan pengalaman akhirnya akan terbentuklah citra diri (self image).

Kedua, biasanya orang akan nervous bila tahu yang dilakukannya akan dinilai orang lain. Untuk menghindari perasaan nervous ini hilangkan persepsi dari penilaian orang, taakut salah, takut malu, takut ditertawai orang dan sebagainya. Bukankah sebelum panda'i berjalan ketika kecil setiap orang selalu jatuh berkali-kali, hingga akhirnya ia bisa berjalan. Ketiga, sering terjadi bila menghadapi situasi asing dan kondisi yang tidak diperhitungkan sebelumnya (tidak saja menjadihambatan bagi pemula, bahkan yang sudah profesionapun sering terganggu dengan kondisi ini).

Ada beberapa langkah yang dapat ditempuh untuk memperkecil General Adaptation Syndroms atau kecemasan dalam berkomunikasi. Secara jangka panjang seorang da'i secara berangsur-angsur mengembangkan keterampilan dalam mengendalikan gejala kecemasan diatas. Secara jangka pendek da'i harus mampu mengendalikan kecemasan tersebut sebelum pidato dilangsungkan.

Pertama-tama yang harus dilakukan dalam menghadapi situasi kecemasan tersebut, adalah dengan melakukan teknik relaksasi untuk mengendurkan otot yang sudah tegang. Tarik napas dalam-dalam, bila perlu teguklah segelas air untuk menyejukkan tenggorokan yang kering, menggoyangkan tangan atau kaki yang gemetar sehingga peredaran darah normal kembali. Teknik yang terbaik untuk mengatasi kecemasan atau syndrom diatas, 
adalah dengan kemampuan menguasai podium, mulailah pidato dengan membuat audiens tertarik dengan lelucon sehingga audiens tertawa dan suasana menjadi segar, tidak tegang, sehingga suasana dialogis dan kondisi psikologi diri sendiri maupun audiens dapat teratasi.

Pada tahap penyampaian pidato, dikenal “tiga rukun' menyampaikan pidato ${ }^{15}$, yaitu kontak, penggunaan symbol bahasa (paralanguage), dan penggunaan isyarat dan gerak tubuh (lambang-lambang nonverbal visual). Dalam sebuah kegiatan pidato terjadi komunikasi dua arah, sehingga perlu dibangun hubungan yang akrap dengan audiens. Da'i harus cerdik menangkap sinyal, mendengarkan pesan yang disampaikan oleh audiens (walaupun sebenarnya da'i lebih mendominasi proses komunikasi tersebut), tetapi pesan yang ingin diketahui dari audiens bukan hanya komentar kata-kata atau ucapan, tetapi pesan yang bukan kata-kata.

Untuk menjalin hubungan yang fimeliar tersebut perlu dilakukan pendekatan dari hati ke hati, melalui pandangan mata yang menyapu seluruh eudiens dari muka sampai belakang, dari kiri sampai kanan dengan mesra, dengan penuh arti. Terjadinya kontak visual akan membawa terjadinya kotak mental, seharusnya umpan balik yang diharapkan dari audiens dapat difahami da'i, sehingga kemana arah dakwah yang direncanakan dapatdirealisir.

Dalam hal tersebut diatas, menurut William Albig perekatan kontak mental sehingga menyebabkan terjadinya pendapat umum tidak bisa dilepaskan dari dasar-dasar psikologi. Menurutnya paling tidak ada delapan ciri yang bisa berproses dalam menciptakan sebuah pendapat umum, yaitu: (a) Reification adalah cara menyajikan sesuatu hal, sesuai objek atau sesuatu gagasan yang asstrak harus dalam bentuk gambaran yang konkrit, tegas dan nyata. (b) Simplication, yakni mengemukakan sesuatu secara sederhana dan mudah difahami. (c) Stereotypes. Kadang-kadang reification dan siplication dapat mewujudkan stereotypes, yaitu standarisasi sesuatu gagasan atau kepercayaan. Akan tetapi, stereotypes yang demikian lebih ditanda'i oleh adanya ketegasan, stabilitas yang terus menerus. (d) Personification yaitu berbagai konsepsi serta masalah yang abstrak dipersonofikasikan. (e) Role of emotions, maksudnya emosi misalnya rasa cinta, benci, takut, terror, amarah, dan sebagainya, daapat melahirkan daya kekuatan yang hebat dalam membentuk pendapat umum, (f) Rationalisation, merupakan istilah yang dipakai untuk menerangkan suatu proses pembenaran berdasarkan alasan-alasan yang logismenyangkut suatu kepercayaan yang dianut atau tindakan yang tengah dilakukan. Adalah manusiawi bilamana manusia selalu mencari rasionalitas atau pembenaran dari pikirannya terhadap apa yang telah diperbuatnya. (h) Opinion Conditioning, maksudnya proses pembentukkan terhadap respon yang otomatis terhadap suatu perangsang tertentu. Ini merupakan seni propaganda yang membentuk respon emosional terhadap kata-kata, peribahasa atau slogan-slogan tertentu.

15 Jalaluddin Rahmad Rhetorika Modern....2002, hlm. 65 
(i), Symbols artinya lambang yang memungkinkan seseorang menyatakan isi hatinya melalui bentuk tertentu sehingga orang lain mengerti, mudah mengingatnya juga mudah dibedakan dari yang lain. ${ }^{16}$

Selain itu perlu juga dikuasai teknik olah vocal yang mengubah bunyi menjadi kata, ungkapan atau kalimat. Pelapalan (erat kaitan dengan ini adalah dialek atau sejenis ragam bahasa menunjukkan cara mengucapkan setiap bunyi, oleh karena itu pelapalan yang kurang benar bukan saja dapat mengaburkan arti, tetapi juga dapat menjatuhkan kredibilitas da'i, lagi pula kesalahan dalam pelapalan dapat mengalihkan perhatian audiens dari pesan ke bunyi, dari isi pembicaraan kepada da'i.

Dalam teknik olah vocal ini da'i perlu memperhatikan keragaman (variety) yang menyangkut nada (Pitch), lama (duration), kecepatan (rate), dan hentian (pauses) ${ }^{17}$. Kapan nada pembicaraan harus tinggi, rendah, sedang? Berapa lama diperlukan untuk mengucapkan satu suku kata? Bagaimana kecepatan mengungkapkan sejumlah kata dalam satu menit? Kapan da'i harus berhenti untuk memberikan kesempatan kepada Audiens untuk mencerna apa yang disampaikan. Da'i perlu memperhatikan intonasi suara, titik koma dalam pembicaraan, tanda Tanya, tanda seru dan sebagainya.

Menyangkut olah visual atau gerakan fisik (physical action) sangat perlu dipelajari da'i dalam melaksanakan pidato. Dalam pidato, gerak fisik digunakan menyampaikan makna, menarik perhatian dan menumbuhkan kepercayaan diri dan semangat. Gerakan fisik dapat dilakukan dengan tangan, kaki, bahu, ekspresi wajah, mata, kerutan dahi, mulut, dan sebagainya. Gerak tubuh yang ditampilkan da'i melibatkan audiens untuk bergerak juga, mereka akan merasakan apa yang sedang dirasakan da'i. Dengan berbicara langsung dari hati maka ekspresi wajah akan muncul dengan sendirinya.

Beberapa panduan dalam melakukan bahasa isyarat yang baik, menurut Glenn R. Capp ${ }^{18}$ sebagai berikut: (a) isyarat yang baik bersifat spontan dan alamiah, jangan membuat-buat isyarat, nanti akan kelihatan lucu; (b) isyarat yang baik mengkoordinasikan seluruh gerak tubuh, seluruh tubuh harus terkoordinasi mengungkapkan hal yang sama; (c) isyarat yang baik dilakukan pada waktu yang terpat, gelengan kepala pada saat mengatakan "tidak", menganggukkan kepala pada saat mengatakan "ya"; (d) syarat yang baik dilakukan penuh, tidak sepotong-potong sebab isyarat yang tidak penuh terjadi ketika da'i ragu bermaksud menggunakan gerak, tetapi kemudian menahannya; (e) kekuatan isyarat harus sesuai dengan gagasan yang di kemukakan; (f) isyarat yang baik harus sesuai dengan besar dan jenis khayalan, gerakan tubuh yang lebih hidup harus dilakukan di depan khalayak anak-anak; (g) isyarat yang baik bervariasi. Jangan terlalu banyak menggunakan satu atau dua isyarat saja.

16Sastropoetro. R.A. Santoso. Propaganda Salah Satu Bantuk Komunukasi Massa.(Bandung: Alumni, 1991), hlm. 172-173 
FITRAH Vol.01 No. 1 Januari-Juni 2015

\section{Pentingnya Penguasaan Retorika Bagi Da'i}

Seni dan kemampuan berbicara di hadapan khalayak ramai saangat dibutuhkan dalam berbagai dimensi kehidupan, apalagi menyangkut profesi atau pekerjaan di bidang hukum (pengacara/hakim/jaksa), guru, menejer sebuah perusahaan, pedagang sampai aparatur pemerintahan. Bahkan bagi seorang da'i retorika menjadi sangat signifikan untuk diketahui dan dikuasai demi kelancaran pekerjaan dakwah.

Sering timbul ditengah masyarakat, seni kemampuan berbicara merupakan bakat sehingga tidak perlu dipelajari. Kenyataannya bakat yang tidak diasah dalam proses pembelajaran dan pelatihan tidak bisa berkembang. Dengan demikian dapat dipahami disamping adanya bakat seni dan kemampuan berbicara di depan khalayak ramai tidak saja dapat dipelajari tetapi mesti diketahui. Perbedaannya mungkin bakat yang telah dimiliki oleh seseorang lebih membantu perkembangan kemampuan beretorika ketimbang orang yang tidak memiliki bakat, mungkin kasus terakhir membutuhkan waktu dan proses belajar dan latihan yang lebih panjang.

Banyak sekali ayat-ayat Al-Quran yang membimbing penggunaan retorika (fannul khitabah) yang baik demi kelancaran dakwah. Dalam surah An-Nahl ayat 125 dijelaskan berdakwah harus menggunakan hikmah, keteladanan dan mujadalah dengan cara yang baik. Mujadalah dalam hal ini difahami sebagai bentuk retorika; (berdiskusi, berdebat dan beragumentasi). Selanjutnya pada surah Fushsilat ayat 33 dinyatakan perkataan (retorika) yang paling baik adalah menyeru kepada jalan Allah.

Selanjutnya cara-cara retorika yang baik adalah "teguh pendirian dalam menjalankan agama, sehingga orang yang didakwah lebih mudah dan cepat mencerna ajakan kepada kebaikan setelah sang pengajak menjalankan perintah agama yang disampaikan tadi' ( lihat Surah Yusuf ayat 108, Surah Ashshafat ayat 12, Surah al- Baqarah ayat 44).

Menyangkut bahasa dakwah yang digunakan berpedoman pada surah al-Baqarah ayat 151, surah ash-Shafat ayat 44, surah Ibrahim ayat4. "Para Rasul memperingatkan dan mengajak kaaumnya dengan bahasa mereka, agar kaum tersebut dapat menerima penjelasan-penjelasan dengan terang dan faham". Begitu juga gaya bahasa retorika yang digunakan dalam berdakwah pada konteks kekinian. Seseorang da'i mestinya menempatkan bahasa yang cocok pada setiap objek dakwahnya. Tempatkan bahasa yang mudah dipahami dan dimengerti oleh audiens, sesuaikan pula dengan kebutuhan yang mereka harapkan. Jangan memberikan makanan kepada orang yang haus, atau member minuman kepada orang yang lapar.

Sikap beretorika yang harus ditampilkan seseorang da'idalam mengemas dakwahnya harus dengan "lemah lembut, penuh kasih sayang terhadap orang beriman, bersikap tegas terhadap mereka yang kafir/ durhaka" (lihat surah Ali Imran ayat 159, surah asy-Syu'araa' ayat 215-216). Dalam menjalankan retorika “tidak mementingkan orang- 
orang yang terkemuka dengan mengabaikan orang-orang yang sungguh-sungguh beriman, walaupun dia terlihat agak hina /rendah" (lihat surah Al-Kahfi ayat 28).

Untuk melancarkan pekerjaan dakwah, seorang da'i harus memiliki persyaratan kredibilitas (source credibility) dan daya tarik (source attractiveness). Menyangkut kredibilitasda'i telah diterangkan pada pembahasan sebelumnya mengenai teknik penyusunan naskah pidato. Da'i yang muncul didepan audiens dengan sendirinya menjadi nara sumber yang layak dipercaya, sebab ketika da'i berani tampil di hadapan banyak orang, tentu saja dia telah mempersiapkan diri, kualitas materi, persiapan mental dan sebagainya. Tidak mungkin seseorang berani tampil menyampaikan sesuatu tetapi dia sendiri tidak tahu apa yang akan disampaikannya. Untuk menyempurnakan pekerjaan dakwah tersebut, seorang da'i harus memperhatikan syarat atraktif (menarik) baik sebelum pidato, sedang pidato maupun setelah pidato dilangsungkan.

Sikap simpatik harus ditunjukkan da'i sebelum naik kemimbar (podium), simpatik bisa berarti mengobral senyum, muka yang manis (tidak cemberut), ramah tamah dan sebagainya. Ketika da'i dipersilahkan naik ke mimbar, pada saat itu dia telah menjadi pusat perhatian audiens, oleh karenanya sikap tenang perlu diupayakan untuk menumbuhkan rasa percaya diri. Sikap percaya diri dapat meminimalkan demam panggung (podium vress).

Ada beberapa cara untuk menghilangkan suasana gugup dan gagap di atas mimbar. Percaya kepada diri sendiri karena sudah melakukan persiapan yang matang, bersikap tenang, tidak memperlihatkan sikap takut (kendatipun audiens yang dihadapi orang-orang pemting, pejabat dan sebagainya) menghirup udara panjang dan dalam tanpa terlihat audiens, menyapu pandangan ke bagian atas mata audiens ( untuk menjinakkan hati dan membuat suasana akrab,karena audiens merasa diperhatikan dan dihargai oleh da'i).

Dalam menyampaikan dakwah di atas mimbar, seorang da'i hendaknya memperlihatkan hal-hal sebagai berikut; pertama, berbicara dengan gaya orisinil, tidak meniru gaya pidato orang lain ( setiap orang memiliki style masing-masing. Jadilah diri sendiri tanpa meniru gaya orang lain). kedua, berbicara dengan sikap sama-sama sederajat (talk with the people), tidak menggurui (talk to the people), ketiga berbicara dengan memperhatikan intonasi suara, tempo suara, titik dan koma harus jelas. Untuk mendapat perhatian perlu melakukan tekanan-tekanan terhadap kalimat atau kata tertentu.Keempat, selalu memelihara personal contact dengan audiens, dengan menunjukkan wajah ceria, simpati sangat bersahabat, kelima, setelah selesai dan saat meninggalkan mimbar, da'i tetap memelihara sikap tenang dan tertib. Turunlah dari mimbar dengan wajah yang penuh ceria dan senyuman manis dengan langkah tegap dan mantap.

Bilamana teknik dan langkah-langkah di atas dipedomani setiap da'i, maka dakwah yang dilakukan nya akan berjalan lancer dan mendapat respon positif dan audiens, baik menyangkut kualitas pribadi, maupun kualitas isi pidato pada gilirannya bermuara pada 
FITRAH Vol.01 No. 1 Januari-Juni 2015

output (perubahan pemahaman, sikap dan action audiens) untuk berjalan sesuai konsep dakwah amar ma'ruf-nahi mungkar.

\section{PENUTUP}

Retorika dalam dakwah dimaksudkan untuk menyampaikan kebenaranAlQurandan Hadis,untuk menggugah audiens mau menjalankan perintah agama dalam dimensi amr ma'ruf nahy mungkar. Secara praktis retorika menjadi keharusan bagida'i untuk menjalankan dakwah secara tertib terencana, tersusun, terkonsep,dan sistematis. Da'i yang membekali kualitas diri dengan prinsip-prinsip retorika dan membangun karakter yang sesuai dengan pedoman Al-Quran dan Hadis membuat dakwah mendapat tempat dan selalu dinantikan audiens. Retorika memang unik, seperti mengemudikan mobil, mudah untuk diketahui tetapi sukar untuk dilakukan, tetapi hadist Nabi saw perlu untuk direnungkan "Barang siapa mengamalkan apa yang ia ketahui Allah Akan mengajarkan dia apa yang tidak ia ketahui." 


\section{DAFTAR PUSTAKA}

A.H. Hasanuddin, Rhetorika Dakwah dan Publisistik dalam Kepemimpinan.Surabaya: Usaha Nasional, 1982.

A.W. Widjaja, Komunikasi dan Hubungan Masyarakat.Jakarta: Bumi Aksara, 1998.

Astrid S.Susanto, Pendapat Umum. Bandung: Binacipta, 1985.

Barker, Ernest. 1962. Greek Philosopy, London: tp

Borman, Ernest G. dan Nancy C, Speech Communication A Basic Approach. Terj. Paulus Sulasdi. Retorika Suatu Pendekatan Terpadu. Jakarta: Erlangga, 1991.

Departemen Agama RI, Al-Quran dan Terjemahnya. Semarang: CV. Toha Putra, 1998.

H. Hamzah Ya'kub, Publisistik Islam Teknik Dakwah dan Leradership. Bandung: CV. Diponegoro, 1986.

Jalaluddin Rahmad, Rhetorika Modern, Pendekatan Praktis. Bandung: PT. Remaja Rosdakarya, 2000 .

Mangunwijaya, Y.B. Pendidikan Manusia Merdeka. Kompas 11 Agustus 1992

Onong Sschjana Effendi, Ilmu Komunikasi Teori dan Praktek. Bandung: PT. Remaja Rosdakarya, 1999.

R.A. Santoso Sastropoetro, Propaganda Salah Satu Bantuk Komunukasi Massa. Bandung: Alumni, 1991.

T.A. Lathief Rousydiy, Dasar dasar Rhetorica Komunikasi dan Informasi, Medan: Firma Rimbow, 1989.

Thomas Colin Coulson, Public Relations a Praktical Guide. Terj. Lucas Ginting, Public Relations Pedoman Praktis Untuk PR. Jakarta: Bumi Aksara, 1993.

Ton.Kertapati, Dasar-Dasar Publisistik Dalam Perkembangannya di Indonesia Menjadi Ilmu Komunikasi. Jakarta: PT. Bina Aksara, 1986.

Toto Tasmara, Komunikasi Dakwah. Jakarta: CV. Gaya Media Pratama, 1987. 
FITRAH Vol.01 No. 1 Januari - Juni 2015

Kajian Sosiologis Tentang Pengaruh Sistem Sosial Budaya Dalam Kehidupan Bermasyarakat 